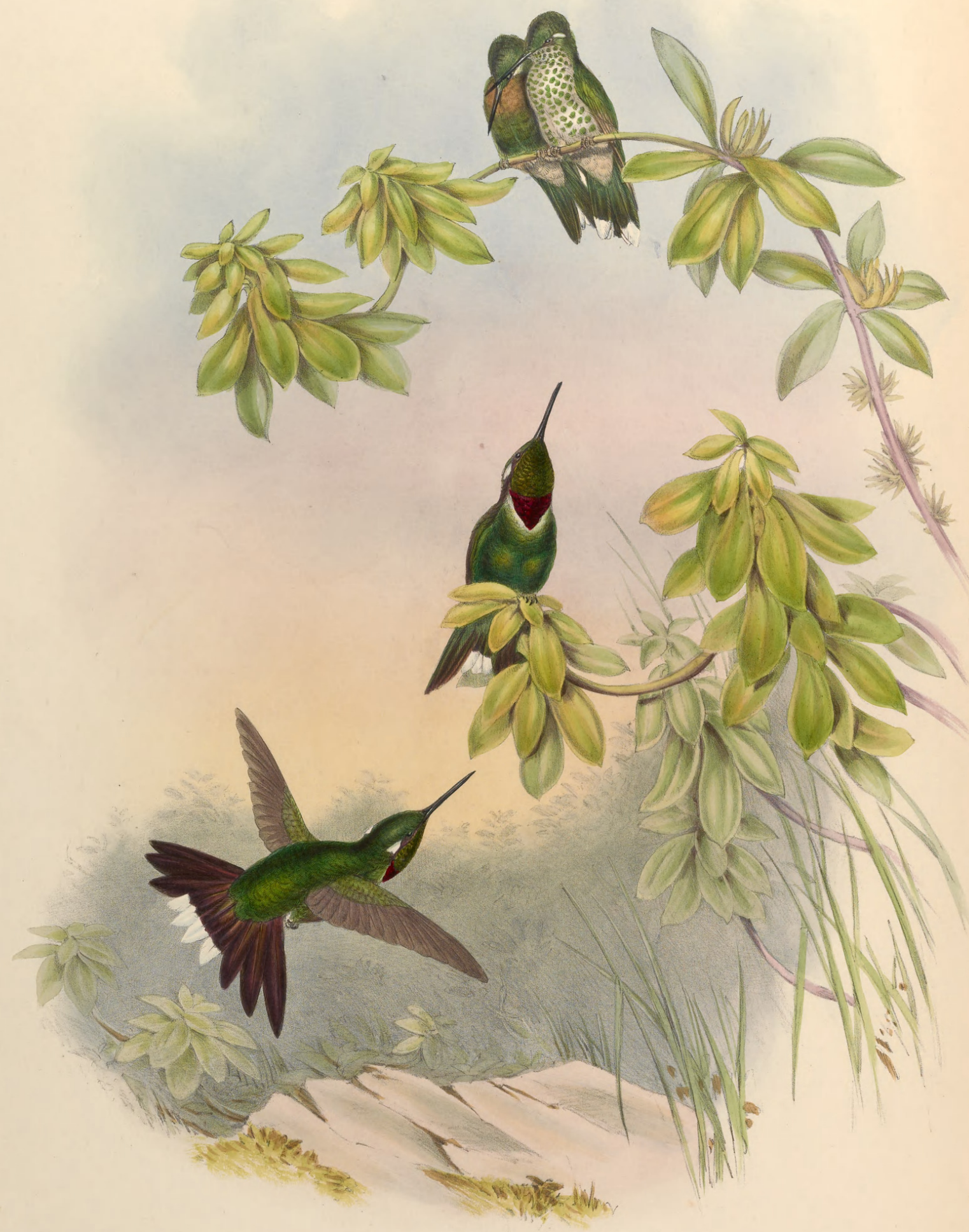




\title{
UROSTICTE BENJAMINI.
}

\author{
White-tip.
}

Trochilus Benjamini, Bourc. Compt. Rend. de l'Acad. des Sci., tom. xxxii. p. 187.

THIs beautiful species, one of the late discoveries in this lovely tribe of birds, differs in so many particulars from every other member of the family, that I have been constrained to give it a new generic title, and have selected that of Urosticte as indicative of the conspicuous white terminations of the four central tail-feathers ; in nearly every other instance it is the outer feathers that are thus marked, and not the central ones, and it is the circumstance of the latter being thus decorated in the present bird which reuders it so remarkable.

For a knowledge of this fine bird we are indebted to M. Bourcier, who discovered it during his residence in Ecuador as the French Consul General for that Republic; and who has named it Benjamini, after the eldest son of Mr. Leadbeater, a name so well known to all naturalists. M. Bourcier states that it inhabits the warm regions in the environs of Gualea; and I have received several examples from Quito, through the hands of Professor Jameson, who procured them on the western side of Pichincha.

The sexes offer a marked difference, as will be seen by the following descriptions :-

The male has the general plumage of the body, both on the upper and under surfaces, green; behind the eye a conspicuous projecting tuft of white; throat luminous green, below which is a gorget-shaped mark of deep reddish violet; wings dark purplish brown; tail bronzy purple, the four central feathers largely tipped with white; bill black; feet brown.

The female has the upper surface green, inclining to bronze on the head; the white tufts behind the eye less conspicuous; all but the two central tail-feathers tipped with white, and the throat and abdomen white, with a spangle of shining green at the tip of each feather.

The young male is dark bronzy green above, dark green below; has the throat rufous, and the four central feathers with an oblong patch of white near the tip.

The Plate represents two males, a young male and a female of the natural size, on a species of Sedum, grown by Sir William Jardine, Bart., at Jardine Hall, from seeds sent to him by Professor Jameson of Quito. 


\section{$2 \mathrm{BHL}$ Biodiversity Heritage Library}

Gould, John. 1857. "Urosticte benjamini, White-tip. [PI. 190]." A monograph of the Trochilidee, or family of humming-birds 3, https://doi.org/10.5962/p.316999.

View This Item Online: https://www.biodiversitylibrary.org/item/109468

DOI: https://doi.org/10.5962/p.316999

Permalink: https://www.biodiversitylibrary.org/partpdf/316999

\section{Holding Institution}

Smithsonian Libraries

\section{Sponsored by}

Smithsonian Institution Libraries

\section{Copyright \& Reuse}

Copyright Status: NOT_IN_COPYRIGHT

This document was created from content at the Biodiversity Heritage Library, the world's largest open access digital library for biodiversity literature and archives. Visit BHL at https://www.biodiversitylibrary.org. 